\title{
Deflowered Revolution: An Ethical Examination of Neo-Liberal Tactics of Pacification
}

\author{
Euripides Altintzoglou
}

\begin{abstract}
During the last two decades we have become familiar with new forms of protest. These new types of protest direct their discontent towards the system in ways that involve the general public, trying to affect change by spreading the feeling of discontent so that governments succumb to wider pressure. These forms of protest are radically different from a strike at a factory or a mine in that they do not affect only those immediately involved - e.g. the owner of a business or multinational companies and government bodies. To a certain extent radical forms of protest such as rioting and looting share this principle. More recently, the Tottenham riots (London, UK) led to widespread looting of retail stores and were heavily criticized for being driven by consumerist desire. This was the view propagated by the media, government officials and surprisingly by leading voices of the left (Bauman, Žižek, Hall). Although we should not be hasty in dismissing looting, we should question the nature of the tactics of any forms of protest that allow themselves to become suspiciously linked with consumerist desire. This is so, because the claim that a desire for goods is the overriding determining factor here aims precisely at deflating the political significance of these riots. By employing Alain Badiou's model of Ethics we are in a position to deal with the root of the problem: what allows for riots that involve looting to be susceptible to the Evils (privations) posed by the accusations of being associated with consumerist desire? What does a public unrest of this nature need in order to avoid ideological demeaning (accusations of consumerist desire) and sustain their fidelity to revolutionary Truth?
\end{abstract}

Key Words: Protest, riot, revolt, looting, ethics, truth, Badiou, Bauman, Žižek, Hall.

$* * * * *$

People who destroy commodities

show their superiority over commodities.

Situationist International ${ }^{1}$

Discussing the nature of rioting in the 1920s Edward Thompson offers three defining characteristics. Firstly, the 'anonymous tradition,' meaning acts of protest could be carried out without an individual being personally persecuted. The second characteristic is what he calls 'counter-theatre': the use of symbolism and ritual during protest. Finally he mentions how riots have the potential to escalate quickly 
and with direct action. It is the characteristic of counter-theatre that is used by rioters as a legitimizing method. ${ }^{2}$ This process of legitimization is necessary for winning public consent or approval, ideally leading to the emergence of solidarity. In Alain Badiou's terms, how can Particularity evolve into Universality in order to attract support from the wider public and eventually affect change?

The current ruling order will do anything in its power to prevent this Universality from manifesting itself. The shooting of Mark Duggan in the summer of 2011 in Tottenham, London, was the event that laid bare the subjective (physical and verbal violence performed by representatives of the state) and objective (social, political and economic alienation imposed by the capitalist system) violent mistreatment of the subaltern and marginalized layers of society. ${ }^{3}$ The Tottenham riots that followed have been heavily criticized on the grounds of being driven by consumerist desire. This view, propagated by the media, official government voices and surprisingly by key voices of the left such as Zygmunt Bauman, Slavoj Zizek and Stuart Hall threatens to overshadow the radical potential and political significance of such events. Bauman, for instance, argues that:

The objects of desire, whose absence is most violently resented, are nowadays many and varied - and their numbers, as well as the temptation to have them, grow by the day. And so grows the wrath, humiliation, spite and grudge aroused by not having them - as well as the urge to destroy what you can't have. Looting shops and setting them on fire derive from the same impulsion and gratify the longing...For defective consumers, those contemporary have-nots, non-shopping is the jarring and festering stigma of a life un-fulfilled - and of own nonentity and good-for-nothingness. Not just the absence of pleasure: absence of human dignity. Of life meaning. Ultimately, of humanity and any other ground for self-respect and respect of the others around. ${ }^{4}$

In an interview with The Guardian Stuart Hall begins to identify the root of the problem although he remains highly dismissive of the political significance of looting:

The riots bothered me a great deal, on two counts. First, nothing really has changed. Some kids at the bottom of the ladder are deeply alienated, they've taken the message of Thatcherism and Blairism and the coalition: what you have to do is hustle. Because nobody's going to help you. And they've got no organized political voice, no organized black voice and no sympathetic voice on the left. That kind of anger, coupled with 
no political expression, leads to riots. It always has. The second point is: where does this find expression in going into a store and stealing trainers? This is the point at which consumerism, which is the cutting edge of neoliberalism, has got to them too. Consumerism puts everyone into a single channel. You're not doing well, but you're still free to consume. We're all equal in the eyes of the market. ${ }^{5}$

In a similar tone Slavoj Zizek resorts to Hegel's notion of 'abstract negativity' in order to brand the Tottenham Riots and similar acts of protest as forms of politically meaningless irrational violence and socially disorganized discontent. He blatantly removes any political significance from both the 2005 Parisian protests by marginalized immigrants and the Tottenham Riots, by asserting they have no 'message to deliver'. Although he blames these and similar movements for their lack for not being able to 'organize themselves into political forces with clear agendas' he goes on to pessimistically dismiss this possibility while branding such acts as violent manifestations of consumerist desire:

Opposition to the system can no longer articulate itself in the form of a realistic alternative, or even as a utopian project, but can only take the shape of a meaningless outburst...More than anything else they were a manifestation of a consumerist desire violently enacted when unable to realize itself in the 'proper' way - by shopping. As such, they also contain a moment of genuine protest, in the form of an ironic response to consumerist ideology: 'You call on us to consume while simultaneously depriving us of the means to do it properly - so we are doing it the only way we can! ${ }^{6}$

Although we should not be critical of looting, we should question the nature of the tactics of forms of protest that are accused of consumerist desire. This is so, because the imposed view that a desire for goods is the overriding determining factor here aims precisely at deflating the political significance of riots. Thus, such a claim works twofold: firstly, it advocates that all revolts that involve looting can be 'bought' and secondly, that those revolts are nothing more than an excessive manifestation of the driving force of capitalism, a feeling very familiar to all of us: the satisfaction of our material desires. In this way, looting is robbed of its radical difference. Moreover, it is proposed as nothing more than an expression of excessive greed, with the only difference being that it is satisfied through illegal means. To put it simply, an analysis of looting in relation to consumerist desire allows for revolutionary acts to be reduced to simple acts of crime, robbing them of any political significance. 
From a historical perspective, to propose that all acts of looting are influenced by modern notions of property and capitalist desire would be to impose a crude generalization. Looting-as-protest emerged before the modern era in riots against early forms of capitalist market tricks. The 'Bread Riots' - born out of allegations of price fixing by withholding grain - is a great example, dating back to the mid18th century and let's not forget that it was a bread riot that escalated into the French Revolution. Bauman seems to think otherwise as in the same article published shortly after the Tottenham Riots he argues that "these are not hunger or bread riots. These are riots of defective and disqualified consumers. ${ }^{7}$ Looting today has the same political content as it always has had, namely, re-appropriating the products of labour by the class of workers. Looting, under capitalism, is a fierce denial of the system of exchange that alienates workers from their products; it rejects the act of consumerism that allows commodities to become fetishized. ${ }^{8}$ However, since it is primarily a tool for protesting the results depend on how it is operated.

The overriding determining factors of these protests were anger, discontent, and defiance towards a political order that sustains an economic system, which makes it difficult for the deprived to achieve the quality of life promised by capitalism; what Karl Marx calls the Lumpenproletariat. ${ }^{9}$ The deprived in this case is not middle-class public sector employees, teachers and lecturers, but it is mostly the unemployed who were later joined by the working class and the petit bourgeois. ${ }^{10}$ Yet, the political and social methods of division applied to these classes have transformed them into what Gayatri Chakravorty Spivak calls the 'subaltern': the marginalized and exploited beyond any dialectical integration. ${ }^{11}$ For Spivak, political movements eventually become exhausted because they fail to engage with the subaltern. But doesn't this presuppose that the subaltern is a passive and politically mollified social entity incapable of engaging itself with the political order? With riots of this nature the subaltern take an active initiative attempting to reengage with the political domain by demonstrating their discontent towards the current economic order.

In our search for a political subject derived from the Tottenham Riots we are faced with a problem that also haunts Kant's account of cognition, namely the synthetic relationship between Understanding - in this case, a diagnosis of a problem - and Imagination - a proposed solution, a plan of action. ${ }^{12}$ Should Imagination precede Understanding, as Kant, and Heidegger argue? Zizek in particular calls this a 'fatal weakness': '[these protests] express an authentic rage, which is not able to transform itself into a positive programme of socio-political change. They express a spirit of revolt without revolution' ${ }^{13}$ Should the rioters have had a full political plan before they initiated their protest? Perhaps the answer is yes but what we should acknowledge is that we are, at the very least, witnessing the becoming of a new potential political subject; one that experiences its own 
Hegelian 'Night of the World' before it emerges as a self-conscious subject, through a series of pre-discursive, pre-rational violent acts. ${ }^{14}$

In Badiou's philosophy a truth procedure initiated by an Event is also a violent act, as it breaks with the ordinary situation in which is takes place. Let us propose for the sake of the argument that the shooting of Mark Duggan constitutes an Event, in so far as it allowed for a Truth to come into being: it 'call[ed] forth and name[d]...the void of the situation', ${ }^{15}$ which is none other than the cause of the subjective and objective violence towards the subaltern. ${ }^{16}$ In his discussion of an ethic of truths, Badiou identifies three manifestations of Evil, all defined by their intent to hamper or corrupt a fidelity to a Truth: firstly, 'simulacrum' - the confusion of a mere simulacrum of an event with a genuine event - secondly, 'betrayal' - the renunciation of a difficult fidelity - and thirdly, 'terror' - the imposition of the total and unqualified power of a truth. ${ }^{17}$ Let us examine the effect of consumerist desire accusations according to these Evils:

Simulacrum: The framing of these riots as acts of stealing driven solely by consumerist desire instigated by those who are not willing to work and earn their goods aspires to present this event as simulacrum - as a problem of a selected few - and thus deny it its universality. Yet at the same time, such claims silently ignore the fact that we are all affected by the capitalist carrot on a stick: we are constantly tempted by more materialist possessions in order to conform to the demands of the system; we are deprived of things we are made to believe that we need.

Fidelity: To reduce these riots to nothing more than a manifestation of consumerist desire implies a weak fidelity to truth. In other words, the rioters were ideologically blinded by the temporary satisfaction of their materialist desire; they neglected their primary emancipatory goals and lost the drive for change. In this way officials try to limit the expansion of the riots and limit the process of legitimization.

Terror: The role of consumerist desire as Terror here is an inverted one. The constant effort by official voices to regulate public opinion through a concerted propaganda maintains that all these rioters want is a replacement of the current system with complete chaos, that their plan is to impose a system that would prevent all of us from acquiring the luxuries promised by the current system. However, simply because the new is different we cannot instantly assume that it leaves no place for difference.

This brings us to the root of the actual problem: what allows for the riots to be susceptible to the Evils posed by the proposed associations with consumerist desire? What does public unrest need in order to avoid a process of ideological demeaning and sustain its fidelity to the Truth? At first, this form of looting as a 
form of protest poses as an act of rejection without the ability to provide a positive alternative; it remains diagnostic, it deals solely with the Understanding of a problem and the identification of its root. In spite of its inherent radicalism, the methodology behind these forms of protest is in fact compatible with the role of moral law in Kantian ethics, in so far as they strive for public consensus by identifying that which is evil, instead of celebrating what is good. ${ }^{18}$ As Badiou argues, it is this obsession with identifying only what is Evil that allows for every revolutionary project to be proposed or rather propagated as a utopian delusion that leads to 'totalitarian nightmare'. ${ }^{19}$ Therefore, the concurrent proposition of an alternative in the form of a political project is of crucial importance, as it acts both as an ideological defence - by proving that the intention is to replace and not to destroy permanently, that destruction paves the way for substitution - and as emancipatory fuel - where the promise of a better alternative enhances solidarity and sustains fidelity to the cause. I am not suggesting here that a given politics should be adopted, as Zizek argues. Instead, the lack of a politicized base sets the conditions for a new politics to emerge, one that truly reflects the conditions of those involved.

Up until the Paris (2007), Athens (2008) and London (2011) riots, symbolism provided rioting and looting with the necessary political focus; the type of focus that accompanies an act of rejection with an equal proposition of an alternative, and which eventually wins public support. This is in fact an old tactic. Adrian Randall, for instance, discusses how symbolism has been adopted in riots in England since the $18^{\text {th }}$ century and the ways that it was employed in order to gain public support through a historical contextualization and rationalization of the aims of the riots. ${ }^{20} \mathrm{~A}$ new form of such symbolism has always been evident in the riots taking place primarily in Southern Europe and wherever the G8 summit is travelling, where symbols of capitalism, the New World Order, the open market etc. are targeted: state and private banks, MacDonald's and Nike stores among many - as well as the old favourites - American embassies and buildings housing Ministries of Finance. This symbolism was always present because these riots were led either by extreme leftist or anarchist groups, where looting acts as the means for a symbolic implementation of chaos and nihilist theories. But as we all know there is a massive difference between destroying the present in order to build a better future and opting for nothingness over nothing at all when there is no plan.

What changed in Paris and London is that those riots where led by non-political groups - in Athens 2008 the riots were led by political groups, mostly anarchist, but it was impoverished illegal immigrants living under horrible conditions that looted shops already destroyed by the rioters. Yet, this does not leave these forms of looting without political significance, one that derives from a fundamental rejection of the current system of exchange. In the UK during the 1980s Margaret Thatcher initiated a long-term plan aimed at eliminating organized political radicalism. Fuelled by the materialist promises of neo-liberalism that plan 
gradually matured in the 1990s. Once this ideological void presents itself it is quickly filled with other non-conformist behaviours: religious fundamentalism or the 'gangster' attitude. Ironically, this attitude has the potential to be even more politically 'destructive' than any other radical movement, simply because its materialist goals have no limits and thus it can never be satisfied; something like consumerist 'desire'.

To summarize, forms of rioting and looting that are not driven by clear political agendas may not sustain an emancipatory politics but they are clear signs of a move away from pacifism. Moreover, we should not reject rioting and looting because at the very least they break with the laws of private property and economic exchange and in this way these acts gain political significance. Political leaders, the guardians of the current order, want us all to condemn riots and looting because they are lawless and violent. But we should defend them. Not because of the physical violence or the useless products that are being looted but because of its inherent promise for the politicization of a generation.

The need of a political agenda should not impose didactic utopian systems of a single leader or thinker. They should rise from forms of collective decision making that reflect specific socio-political conditions, not drawn from the past; what has not survived is not worth reviving. It should not be the better version of this or that political system imposed by an authoritarian intellectual voice or lured in by the materialist offers of the market. At the same time, a new political subjectivity cannot appear in a perfect form through a divine parthenogenesis but can only emerge out of a violent dialectic process, a Night of the World. For a revolution to last, it needs to produce its own politics: an Event producing its own Truth.

\section{Notes}

${ }^{1}$ Situationist International, 'The Decline and Fall of the Spectacle-Commodity Economy,' Situationist International Anthology, trans. K. Knabb (Berkley: Bureau of Public Secrets, 2006), 197.

2 Edward P. Thompson, 'The Moral Economy of the English Crowd in the Eighteenth Century,' Past and Present 50 (1971): 76-136.

${ }^{3}$ Slavoj Žižek, Violence (London: Profile Books, 2009).

4 Zygmunt Bauman, 'The London Riots: On Consumerism Coming Home to Roost,' Social Europe Journal, 9 August 2011, Viewed 17 June 2014, http://www.social-europe.eu/2011/08/the-london-riots-on-consumerism-cominghome-to-roost/.

5 Stuart Hall, 'The Saturday Interview: Stuart Hall by Zoe Williams,' The Guardian, 11 February 2012, Viewed 17 June 2014, http://www.theguardian.com/theguardian/2012/feb/11/saturday-interview-stuarthall. 
${ }^{6}$ Slavoj Žižek, 'Shoplifters of the World Unite,' London Review of Books, 19 August 2011, Viewed 17 June 2014, http://www.lrb.co.uk/2011/08/19/slavoj-zizek/shoplifters-of-the-world-unite.

${ }^{7}$ Zygmunt Bauman, 'The London Riots'.

${ }^{8}$ Situationist International, 'The Decline and Fall of the Spectacle-Commodity Economy,' 197.

${ }^{9}$ Karl Marx, The Eighteenth Brumaire of Louis Bonaparte (Rockville: Serenity Publishers, LLC, 2008), chapter V.

${ }^{10}$ As George Rude argues, riots are rarely socially homogenous. George Rude, The Crowds in the French Revolution (Oxford: Oxford University Press, 1967).

${ }^{11}$ Gayatri Chakrakravorty Spivak, The Critique of Postcolonial Reason: Toward a History of the Vanishing Present (Cambridge: Harvard University Press, 1999), 175.

12 Immanuel Kant, Critique of Pure Reason, trans. P. Guyer and A. Wood (Cambridge and New York: Cambridge University Press, 1997).

${ }^{13}$ Slavoj Žižek, 'Shoplifters of the World Unite'.

14 G. W. F. Hegel, 'Jenaer Realphilosophie,' in Frühe Politische Systeme (Frankfurt: Ullstein, 1974).

15 Alain Badiou, Ethics: An Essay on the Understanding of Evil, trans. Peter Hayward (London: Verso, 2002), 72.

${ }^{16}$ Slavoj Žižek, Violence.

${ }^{17}$ Alain Badiou, Ethics.

${ }^{18}$ Immanuel Kant, Religion and Rational Theology, trans. and ed. A. W. Wood and G. diGiovanni (Cambridge and New York: Cambridge University Press, 1996).

19 Alain Badiou, Ethics: An Essay on the Understanding of Evil (London, New York: Verso, 2001), 13.

${ }^{20}$ Adrian Randall, Riotous Assemblies: Popular Protest in Hanoverian England (Oxford, Oxford University Press, 2006).

\section{Bibliography}

Badiou, Alain. Ethics: An Essay on the Understanding of Evil. London \& New York: Verso, 2001.

Bauman, Zygmunt. 'The London Riots: On Consumerism Coming Home to Roost.' Social Europe Journal, August 9, 2011. Viewed 17 June 2014. http://www.social-europe.eu/2011/08/the-london-riots-on-consumerism-cominghome-to-roost/. 
Hall, Stuart. 'The Saturday Interview: Stuart Hall by Zoe Williams.' The Guardian, February 11, 2012. Viewed 17 June 2014.

http://www.theguardian.com/theguardian/2012/feb/11/saturday-interview-stuarthall.

Kant, Immanuel. Critique of Pure Reason. Translated and edited by P. Guyer and A. Wood. Cambridge and New York: Cambridge University Press, 1997.

Kant, Immanuel. Religion and Rational Theology. Translated and edited by A. W. Wood and G. di Giovanni. Cambridge and New York: Cambridge University Press, 1996.

Knabb, Ken. Situationist International Anthology. Berkley: Bureau of Public Secrets, 2006.

Marx, Karl. The Eighteenth Brumaire of Louis Bonaparte. Rockville: Serenity Publishers, LLC, 2008.

Randall, Adrian. Riotous Assemblies: Popular Protest in Hanoverian England. Oxford: Oxford University Press, 2006.

Rude, George. The Crowds in the French Revolution. Oxford: Oxford University Press, 1967.

Spivak, Gayatri Chakrakravorty. The Critique of Postcolonial Reason: Toward a History of the Vanishing Present. Cambridge: Harvard University Press, 1999.

Thompson, Edward P. 'The Moral Economy of the English Crowd in the Eighteenth Century.' Past and Present 50 (1971): 76-136.

Žižek, Slavoj. Violence. London: Profile, 2008.

Žižek, Slavoj. 'Shoplifters of the World Unite.' London Review of Books, August 19, 2011. Viewed 17 June 2014.

http://www.lrb.co.uk/2011/08/19/slavoj-zizek/shoplifters-of-the-world-unite.

Žižek, Slavoj. The Ticklish Subject: The Absent Centre of Political Ontology, London: Verso, 1999. 
Euripides Altintzoglou is a Senior Lecturer in Photography at the University of Wolverhampton. A practicing artist and a writer whose work critically engages with the dialectical interrelation of politics and art. 